\title{
Aansluitingsproblematiek op de regionale arbeidsmarkt
}

Citation for published version (APA):

Bertrand-Cloodt, D. A. M., Cörvers, F., \& van Thor, J. A. F. (2011). Aansluitingsproblematiek op de regionale arbeidsmarkt. ROA. ROA Technical Reports No. 002 https://doi.org/10.26481/umarot.2011002

Document status and date:

Published: 01/01/2011

DOI:

10.26481/umarot.2011002

Document Version:

Publisher's PDF, also known as Version of record

\section{Please check the document version of this publication:}

- A submitted manuscript is the version of the article upon submission and before peer-review. There can be important differences between the submitted version and the official published version of record.

People interested in the research are advised to contact the author for the final version of the publication, or visit the DOI to the publisher's website.

- The final author version and the galley proof are versions of the publication after peer review.

- The final published version features the final layout of the paper including the volume, issue and page numbers.

Link to publication

\footnotetext{
General rights rights.

- You may freely distribute the URL identifying the publication in the public portal. please follow below link for the End User Agreement:

www.umlib.nl/taverne-license

Take down policy

If you believe that this document breaches copyright please contact us at:

repository@maastrichtuniversity.nl

providing details and we will investigate your claim.
}

Copyright and moral rights for the publications made accessible in the public portal are retained by the authors and/or other copyright owners and it is a condition of accessing publications that users recognise and abide by the legal requirements associated with these

- Users may download and print one copy of any publication from the public portal for the purpose of private study or research.

- You may not further distribute the material or use it for any profit-making activity or commercial gain

If the publication is distributed under the terms of Article $25 \mathrm{fa}$ of the Dutch Copyright Act, indicated by the "Taverne" license above, 
Maastricht University

Research Centre for Education and the Labour Market | ROA

\section{Aansluitingsproblematiek op de regionale arbeidsmarkt}

D. Bertrand-Cloodt

F. Cörvers

J. van Thor

\section{ROA Technical Report}

ROA-TR-2011/2

Research Centre for Education and the Labour Market Maastricht University

P.O. Box 616, 6200 MD Maastricht, The Netherlands

$\mathrm{T}+31433883647 \mathrm{~F}+31433884914$

secretary-roa-sbe@maastrichtuniversity.nl www.roa.nl 


\section{Aansluitingsproblematiek op de regionale arbeidsmarkt}

D. Bertrand-Cloodt

F. Cörvers

J. van Thor

ROA-TR-2011/2

december 2011

Research Centre for Education and the Labour Market

Maastricht University

P.O. Box 616, 6200 MD Maastricht, The Netherlands

$\mathrm{T}+31433883647 \mathrm{~F}+31433884914$

secretary-roa-sbe@maastrichtuniversity.nl

www.roa.nl 


\section{Voorwoord}

Dit rapport $^{1}$ maakt deel uit van het Project Onderwijs-Arbeidsmarkt (POA). Dit project wordt gefinancierd door het Ministerie van Onderwijs, Cultuur en Wetenschap (OCW), het Uitvoeringsinstituut Werknemersverzekeringen (UWV), het UWV WERKbedrijf, het Ministerie van Economische Zaken, Landbouw en Innovatie (EL\&I), de samenwerkende kenniscentra voor beroepsonderwijs en bedrijfsleven COLO, Randstad Nederland en de Raad voor Werk en Inkomen (RWI).

${ }^{1}$ Het onderzoek is uitgevoerd als verkennende studie in het kader van het Project Onderwijs-Arbeidsmarkt (POA). De resultaten van het onderzoek zijn slechts indicatief en voorlopig doordat er gebruik is gemaakt van een aantal naïeve veronderstellingen en modellen. 


\section{Introductie}

Dit werkdocument gaat over de regionale aansluitingsproblematiek. Deze studie wordt uitgevoerd vanwege de toegenomen interesse in regionale arbeidsmarktinformatie, en de waarde die wordt gehecht aan de samenwerking tussen het bedrijfsleven en ROC's in de regio's. Bovendien komt de studie in aanmerking als toekomstig themahoofdstuk in de arbeidsmarktrapportage die volgt op De arbeidsmarkt naar opleiding en beroep tot 2014 van november 2009.

In tegenstelling tot het hoger onderwijs heeft het middelbaar beroepsonderwijs een belangrijke regionale functie. Werkgevers in verschillende regio's klagen vaak over de toelevering van MBO'ers in hun regio door de plaatselijke ROC's. Het betreft dan zowel de volgens werkgevers vaak verkeerde opleidingskeuze van jongeren in de betreffende regio's als de onvoldoende competenties van deze jongeren. Het Ministerie van OCW heeft onder meer om deze reden in het verleden de regionale functie van ROC's sterk benadrukt (bijv. Koers BVE). Tevens bestaan er diverse Regionale Platforms Arbeidsmarktbeleid (RPA's, met vaak vertegenwoordiging van het onderwijs, het bedrijfsleven en het CWI), en is er een lappendeken van provincies, gemeentes of regio's binnen provincies, en heel verschillende instanties (regionale SER's, regionale Kenniscentra van COLO, ad hoc samenwerkingsverbanden) die op één of andere wijze de regionale aansluiting tussen onderwijs en arbeidsmarkt trachten te verbeteren. Daarnaast zijn er nog allerlei andere instanties die op sectoraal niveau samenwerken aan het stimuleren van een goede aansluiting.

De Commissie Arbeidsparticipatie ('Bakker') beveelt in haar advies van 16 juni 2008 aan om meer gebruik te maken van de kracht van de regio en om de aansluiting tussen onderwijs en arbeidsmarkt te verbeteren. In het voorliggende onderzoek wordt nagegaan hoe goed of slecht de aansluiting op MBO-niveau is in de verschillende regio's, en in welke mate contacten tussen bedrijfsleven en onderwijsinstellingen alsmede de verschillende instituties op het terrein van arbeidsmarktbeleid in een regio het verschil maken. 


\subsection{Indicatoren voor aansluiting en opleidingskenmerken}

Voor het meten van de kwaliteit van de aansluiting tussen school en werk is gebruik gemaakt van een (voorlopig eenmalige) sterke uitbreiding van het schoolverlatersonderzoek (SchoolverlatersInformatieSysteem - SIS) van het ROA onder MBO-gediplomeerden. Deze gediplomeerden zijn circa anderhalf jaar na afstuderen geënquêteerd. De steekproef die in het najaar en de winter van 2008/2009 is gehouden heeft een relatief goede regionale dekking, waardoor gegevens die doorgaans alleen landelijk kunnen worden uitgesplitst naar opleidingsrichting nu ook op regionaal niveau samen te stellen zijn. Het gaat hierbij om antwoorden van schoolverlaters op vragen als: hoe is de aansluiting tussen de gevolgde MBOopleiding en je huidige functie? Als indicatoren voor de aansluiting tussen de opleiding en de arbeidsmarkt worden in de analyses twee variabelen gebruikt. De eerste variabele voor aansluiting bestaat uit vier antwoordcategorieën (slecht, matig, voldoende en goed), de tweede bestaat uit twee antwoordcategorieën (onvoldoende versus voldoende).

Als kenmerken voor de opleiding worden het niveau en de richting van de opleiding als verklarende variabelen in de analyses meegenomen. Tevens wordt er een variabele gebruikt die aangeeft of de MBO-gediplomeerden een BOL- of BBL-opleiding gevolgd hebben.

\subsection{Indicatoren arbeidsmarkt en beleidsinspanningen}

Voor de verklaring van de verschillen tussen regio's wat betreft de aansluiting tussen onderwijs en arbeidsmarkt is gekeken naar de algehele arbeidsmarktsituatie in een regio, regionale kenmerken, indicatoren die beleidsinspanningen weergeven en indicatoren die de samenwerking tussen ROC's en het bedrijfsleven weergeven. Voor de regio-indeling naar corop-gebied en de indicatoren op regioniveau is gebruik gemaakt van gegevens die verkregen zijn via CBS StatLine.

\subsubsection{De algehele arbeidsmarktsituatie in een regio}

Voor de indeling naar regio's is gebruikt gemaakt van de corop-indeling naar 40 Nederlandse corop-gebieden van het CBS. Voor het meten van de algehele arbeidsmarktsituatie in een regio worden het werkloosheidspercentage, de vacaturegraad en de bruto participatiegraad per regio als verklarende variabelen meegenomen. Het werkloosheidspercentage bestaat uit de werkloze beroepsbevolking gedeeld door de totale beroepsbevolking. De vacaturegraad wordt 
hier gedefinieerd als het aantal vacatures van middelbaar onderwijsniveau gedeeld door de werkzame beroepsbevolking van middelbaar onderwijsniveau. De bruto participatiegraad geeft het aandeel van de (werkzame en werkloze) beroepsbevolking van middelbaar onderwijsniveau weer in de potentiële beroepsbevolking van middelbaar onderwijsniveau.

\subsubsection{Regionale kenmerken}

Bij de regionale kenmerken wordt er gekeken naar demografische factoren alsook naar de economische structuur van een regio. Voor de demografische factoren worden het percentage jongeren, het percentage ouderen en de mate van vergrijzing gebruikt. Het percentage jongeren geeft het percentage jongeren in de leeftijd van 15 tot 25 weer ten opzichte van de totale bevolking in die specifieke regio. Het percentage ouderen geeft per corop-gebied het percentage van de werkzame beroepsbevolking weer dat 55 jaar of ouder is. Vergrijzing is hier gemeten als het percentage van de bevolking dat 65 jaar of ouder is.

De variabelen landbouw, nijverheid/energie, commerciële dienstverlening en nietcommerciële dienstverlening worden in de analyses meegenomen als indicatoren voor de economische structuur van een regio en geven het percentage bedrijfsvestigingen weer naar activiteit op 1 januari 2008. Bedrijven hebben één of meer vestigingen. De meeste bedrijven bestaan uit één vestiging, een klein deel van de bedrijven heeft meer dan een vestiging. Meerdere locaties van een bedrijf binnen één postcodegebied worden als één vestiging beschouwd. Het totaal aantal vestigingen is afgeleid uit het aantal geregistreerde eenheden uit het Algemene Bedrijvenregister van het CBS en uit het aantal agrarische vestigingen volgens de Landbouwtelling van het CBS.

\subsubsection{Indicatoren voor beleidsinspanningen in een regio}

De variabele RPA (Regionaal Platform Arbeidsmarkt) geeft het bestaan van RPA's weer in een regio. Sommige RPA's zijn opgeheven of zijn voortgezet onder een andere naam, als bijvoorbeeld Platform Onderwijs, Werk en Inkomen (POWI), Platform Onderwijs Arbeidsmarkt (POA) of Platform Arbeidsmarkt en Onderwijs (PAO). ${ }^{2}$ Wanneer een specifiek corop-gebied behoort tot het werkgebied van een RPA dan wordt de variabele RPA gecodeerd als ' 1 '. Wanneer een regio niet fungeert als werkgebied voor een RPA dan wordt deze variabele gecodeerd als ' 0 '.

\footnotetext{
${ }^{2}$ Zie bijlage voor meer informatie met betrekking tot de huidige stand van zaken van RPA's.
} 


\subsubsection{Indicatoren voor de samenwerking tussen ROC's en het bedrijfsleven}

Als indicator voor de samenwerking tussen ROC's en het bedrijfsleven wordt de variabele BBL regio gebruikt. Deze variabele geeft het percentage BBL'ers in een regio weer.

\subsubsection{Controle variabelen}

Naast bovengenoemde variabelen worden er ook een aantal controle variabele meegenomen, zowel op individueel als op regionaal niveau. De controle variabelen op individueel niveau zijn geslacht, leeftijd en etniciteit. De variabele niet-westerse allochtoon geeft de etniciteit weer op individueel niveau $(1=$ niet-westerse allochtoon en $0=$ westerse allochtoon $/$ autochtoon).

Op regionaal niveau worden de etniciteit en de woningwaarde als controle variabelen gebruikt. De etniciteit wordt weergegeven door de variabele niet-westerse allochtoon regio, deze geeft per regio het aantal niet-westerse allochtonen weer als percentage van het totaal aantal inwoners op 1 januari 2008. De variabele woningwaarde is de gemiddelde woningwaarde in een regio.

\section{Werkloosheidspercentage en vacaturegraad curve (UV-curve)}

\subsection{Literatuur}

Volgens de economische geografie is het vermogen van landen om zich economisch te ontwikkelen geworteld in het vermogen om zich op regionaal niveau te specialiseren (Hilbert, 2008). Zo kunnen comparatieve voordelen ontstaan voor regio's die zich specialiseren door toenemende regionale schaalvoordelen. Vanuit dit perspectief kan ook gekeken worden naar verschillen in vraag en aanbod op regionale arbeidsmarkten om zodoende verschillen in het niveau van de aansluiting tussen regio's te verklaren. Regio's waarin veel instanties gevestigd zijn die vraag en aanbod op de arbeidsmarkt bij elkaar trachten te brengen zullen volgens deze gedachtegang efficiënter en dus succesvoller zijn dan regio's waar dit in mindere mate het geval is.

De aansluitingsproblematiek op de arbeidsmarkt wordt in de economische literatuur vaak beschreven door middel van een zogenaamde 'unemployment-vacancy' (UV-) curve, ofwel 'Beveridge curve' (e.g. Blanchard \& Diamond, 1989, Börsch-Supan, 1991, Van Ours, 1991 en Wall \& Zoega, 2002). Het uitgangspunt van deze curve is een matchingsfunctie waarin het 
werkloosheidspercentage (unemployment rate) wordt afgezet tegen de vacaturegraad (vacancy rate). Aangezien een UV-analyse het verband weergeeft tussen het aantal openstaande vacatures en de werkloosheid kan deze analyse als indicator dienen voor de efficiëntie van het matchingsproces tussen vraag en aanbod op de arbeidsmarkt (Valletta, 2005).

UV-curves laten doorgaans een negatief verband zien tussen het werkloosheidspercentage en de vacaturegraad. Als de vacaturegraad afneemt (c.q. toeneemt), neemt de werkloosheid met enige vertraging toe (c.q. af). Doordat de werkloosheid later reageert op veranderingen in de economische groei dan de vacaturegraad ontstaan er cirkels in de figuur die de UV-curve weergeeft. De conjuncturele ontwikkeling wordt weergegeven door een beweging langs de curve. Wanneer de conjunctuur namelijk aantrekt, stijgt de vacaturegraad en neemt tegelijkertijd het werkloosheidspercentage af. Wanneer een UV-curve in noordoostelijke richting verschuift, i.e. een hogere werkloosheid bij dezelfde vacaturegraad of een hogere vacaturegraad bij dezelfde werkloosheid, kan dit duiden op een grotere mismatch op de arbeidsmarkt. Vraag en aanbod op de arbeidsmarkt kunnen dan namelijk slechter op elkaar aansluiten. Daarnaast is het mogelijk dat de arbeidsmarkt minder efficiënt functioneert dan voorheen doordat bijvoorbeeld de transparantie is afgenomen of de registratie van werklozen en vacatures is vertraagd, waardoor werklozen en werkgevers langer moeten zoeken om een passende baan c.q. geschikte kandidaat te vinden. Andere mogelijke oorzaken die vaak aangedragen worden zijn bijvoorbeeld structurele veranderingen van het arbeidsmarktaanbod of de -vraag, een afnemende zoekintensiteit van werkzoekenden of een toename van de selectiviteit van werkgevers (Gorter \& Van Ours, 1994). Een sluitend antwoord op de verschuiving van de UV-curve is echter niet voorhanden.

Vaak worden UV-analyses toegepast op nationaal niveau. Zodoende kan in kaart gebracht worden of de aansluiting tussen vraag en aanbod op de arbeidsmarkt van een bepaald land goed is of dat er juist sprake is van een mismatch. Verschillende studies over de UV-curve van Nederland en andere Europese landen wijzen bij een verschuiving in noordoostelijke richting op een slechter functionerende arbeidsmarkt, maar een andere verklaring voor deze verschuiving lijkt aannemelijker (Van Ours, 1991). Van Ours (1991) ziet fluctuaties aan de vraagzijde als oorzaak van deze verschuiving, welke 'loopings' veroorzaken die tegen de klok 
in bewegen. ${ }^{3}$ Een daling van de werkgelegenheidsgroei leidt in dergelijke gevallen tot een dalende vacaturegraad bij aanvankelijk gelijkblijvende werkloosheid. ${ }^{4}$

De mate van mismatch op de arbeidsmarkt kan echter ook op een lager aggregatieniveau onderzocht worden. Dit is bijvoorbeeld interessant om de aansluitingsproblematiek in verschillende regio's in kaart te brengen. Verschillende empirische arbeidsmarktstudies onderzoeken deze aansluiting tussen vraag en aanbod dan ook op subnationaal niveau om zo een indicatie te kunnen geven van de aansluiting in deze regio's. Voorbeelden hiervan zijn de empirische studies van Börsch-Supan (1991) die de aansluitingsproblematiek vergelijkt tussen verschillende Duitse regio's, Gorter \& Van Ours (1994) voor verschillende regio's in Nederland, Wall \& Zoega (2002) voor verschillende regio's in Groot-Brittannië en Valletta (2005) voor verschillende regio's in de Verenigde Staten.

Gorter en Van Ours (1994) onderzoeken regionale ontwikkelingen op het gebied van werkloosheid en openstaande vacatures in Nederland gedurende de jaren '80. Het doel van hun studie is om te achterhalen in welke mate verschillen in werkloosheid en vacaturegraad toegewezen kunnen worden aan regionale arbeidsmarktbeleidsinspanningen. In een spreidingsdiagram zetten zij voor iedere provincie het werkloosheidspercentage af tegen de vacaturegraad. In 1980 was de spreiding van de vacaturegraden groter dan de spreiding van de werkloosheidspercentages, terwijl dit in 1988 juist omgekeerd was. De regionale arbeidsmarkten van Friesland, Drenthe, Zeeland en Noord-Brabant blijken in deze studie het meest efficiënt te zijn, terwijl de regionale arbeidsmarkten van Limburg, Zuid-Holland en Gelderland het minst efficiënt zijn. Een relatief hoge mate van efficiëntie in een regio betekent in dit geval dat werkzoekenden en werkgevers minder kieskeurig zijn in hun selectiegedrag of dat zij elkaar sneller weten te vinden.

In het algemeen concluderen Gorter en Van Ours (1994) dat de verschillen in de efficiëntie van het matchingsproces tussen de verschillende provincies niet al te groot zijn. Dit lijkt er daarom op te wijzen dat ongunstige regionale arbeidsmarktomstandigheden vooral veroorzaakt worden door een gebrek aan regionale vraag naar arbeid. Beleidsinspanningen

\footnotetext{
${ }^{3}$ Loopings die met de klok mee bewegen worden daarentegen veroorzaakt door een toename van het arbeidsmarktaanbod.

${ }^{4}$ Zie voor meer informatie over de Nederlandse UV-curve ROA (2007), De arbeidsmarkt naar opleiding en beroep tot 2012, ROA-R-2007/4, Universiteit Maastricht.
} 
betreffende de regionale arbeidsmarkt zouden volgens deze studie dan ook met name gericht moeten zijn op het stimuleren van arbeidsmarktvraag om zodoende werkloosheidscijfers omlaag te brengen.

\subsection{Geschatte verbanden voor regionale aansluiting}

De regionale aansluiting wordt in deze paragraaf op twee verschillende manieren geanalyseerd. Allereerst wordt in paragraaf 3.2.1 voor de 40 Nederlandse corop-gebieden gekeken naar de kwantitatieve aansluiting. Vervolgens komt in paragraaf 3.2.2 de door MBOgediplomeerden ervaren aansluiting van genoemde regio's aan bod. Tot slot wordt er gekeken of er sprake is van een verband tussen beide vormen van regionale aansluiting.

\subsubsection{Kwantitatieve regionale aansluiting}

Figuur 1 geeft door middel van een UV-curve het lineaire verband weer tussen de vacaturegraad en het werkloosheidspercentage voor MBO-gediplomeerden van de 40 Nederlandse corop-gebieden in 2008 (CBS StatLine). ${ }^{5}$ Elk punt in de figuur laat voor het bijbehorende corop-gebied zien hoe hoog het werkloosheidspercentage van MBOgediplomeerden is bij een gegeven vacaturegraad in dat gebied. Wanneer er in een bepaalde regio veel werkloosheid is ten opzichte van het aantal openstaande vacatures, dan betekent dit dat er sprake is van een slechte match tussen vraag en aanbod op die regionale arbeidsmarkt. Als er sprake is van een lage werkloosheid bij een gegeven vacaturegraad wijst dit op een goede aansluiting.

Aangezien de mate van werkloosheid en de vacaturegraad uitgedrukt zijn in getallen, of om precies te zijn in percentages, geeft de UV-curve informatie over de kwantitatieve regionale aansluiting. De vraagzijde van de arbeidsmarkt is hier 'driver', i.e. wanneer het aantal openstaande vacatures in een regio stijgt of daalt dan resulteert dit in een effect op het werkloosheidsniveau in die regio.

De rode lijn in Figuur 1 geeft het geschatte lineaire verband weer tussen de vacaturegraad en het werkloosheidspercentage voor MBO-gediplomeerden voor de verschillende regio's in 2008. In het algemeen kan gesteld worden dat er sprake is van een significant negatief

5 Het corop-gebied Delfzijl en omgeving (punt 2) wordt niet in de figuur weergegeven. Het werkloosheidspercentage in deze regio is namelijk dermate hoog $(9,1 \%)$ dat het de vergelijking van de overige regio's zou bemoeilijken indien het meegenomen zou worden in deze figuur. 
verband $(\beta=-0,353)$ tussen het aantal openstaande vacatures en het werkloosheidsniveau in de onderzochte regio's. Dit negatieve verband is significant bij een $95 \%$ betrouwbaarheidsinterval ( $\mathrm{p}$-waarde $=0,017$ ). Hoe meer werkloosheid er dus per vacaturegraad is, hoe slechter de aansluiting. De oranje en de groene lijn in de figuur duiden de bandbreedte aan en geven respectievelijk weer of er sprake is van een slechte dan wel een goede aansluiting tussen vraag en aanbod op de arbeidsmarkt. ${ }^{6}$

Figuur 1 De kwantitatieve regionale aansluiting: de UV-curve, MBO-gediplomeerden in 2008

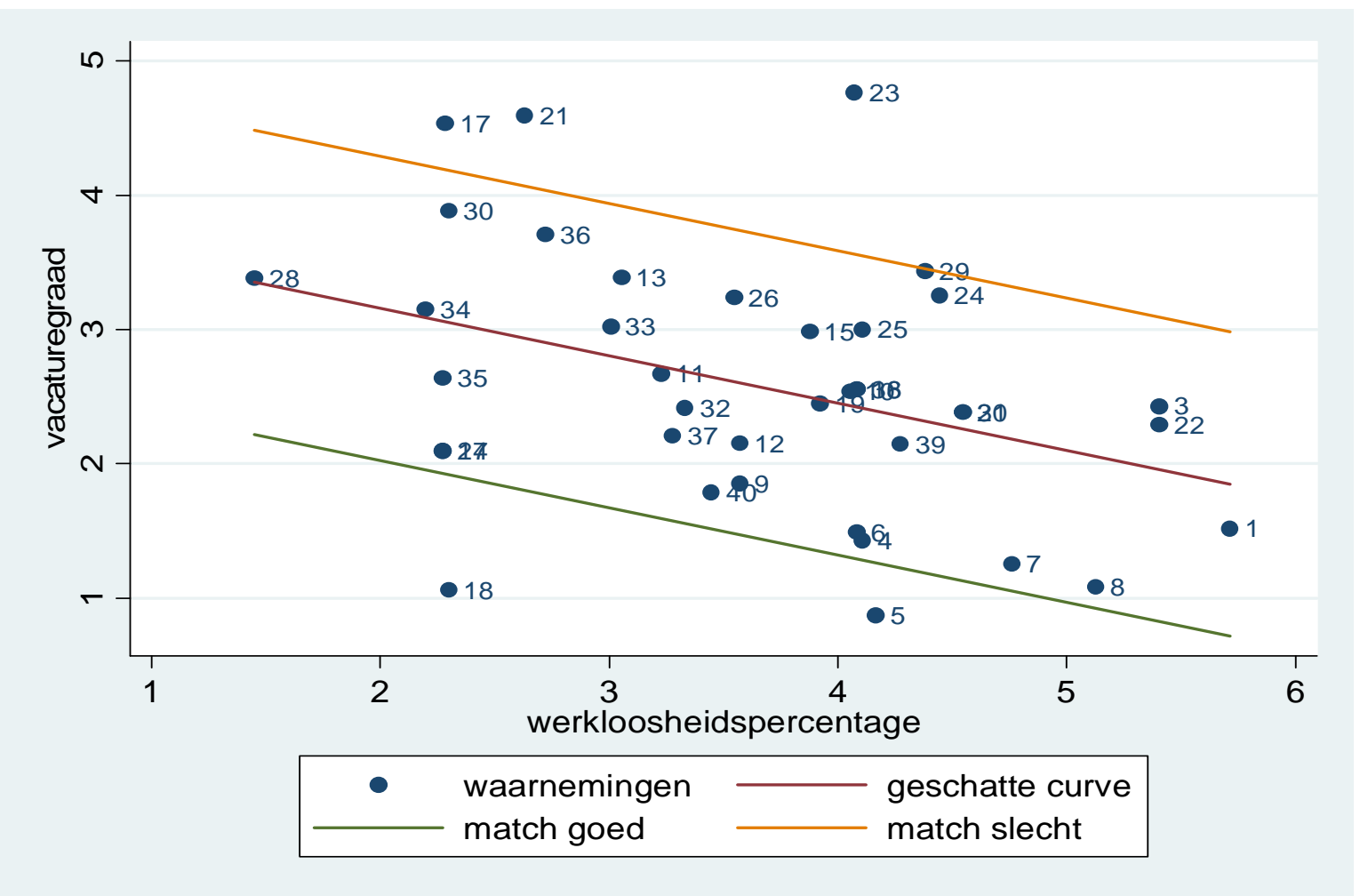

Bron: CBS (StatLine)

Hierna wordt de aansluiting voor de verschillende afzonderlijke corop-gebieden in Figuur 1 besproken. Wanneer we bijvoorbeeld kijken naar Kop van Noord-Holland (punt 18), dan valt op dat dit punt een behoorlijk stuk onder de groene bandbreedtelijn ligt. Dit betekent dat er, gegeven de vacaturegraad in Kop van Noord-Holland, een relatief lage werkloosheid in deze regio is. Derhalve kan geconcludeerd worden dat de aansluiting tussen vraag en aanbod op deze regionale arbeidsmarkt beter dan gemiddeld is en als goed getypeerd kan worden.

\footnotetext{
${ }^{6}$ Bij de keuze voor deze bandbreedte is enige mate van voorzichtigheid in acht genomen en daarom is de bandbreedte vastgesteld op maar liefst acht maal de standaarddeviatie. Dit om ervoor te zorgen dat alleen die corop-gebieden getypeerd worden als gebieden met een goede cq. slechte aansluiting, die ook daadwerkelijk behoorlijk van het gemiddelde afwijken.
} 
Hetzelfde kan geconcludeerd worden voor Zuidwest-Friesland (punt 5). In vergelijking met de aansluiting in Kop van Noord-Holland scoort Zuidwest-Friesland echter aanmerkelijk slechter. Bedraagt het werkloosheidspercentage in Kop van Noord-Holland 2,3\% bij een vacaturegraad van ongeveer $1 \%$, in Zuidwest-Friesland bedraagt het werkloosheidspercentage $4,2 \%$ bij een vacaturegraad van bijna $1 \%$.

Voor Utrecht (punt 17), Agglomeratie Haarlem (punt 21) en Groot-Amsterdam (punt 23) geldt juist het tegenovergestelde als voor Kop van Noord-Holland en Zuidwest-Friesland. Zoals blijkt uit de figuur is er in deze regio's namelijk juist sprake van een slechte aansluiting. De regionale aansluiting van Groot-Rijnmond (punt 29) ligt daarbij nog net op de grens tussen een slechte en een matige aansluiting. Voor Utrecht geldt bijvoorbeeld dat het werkloosheidspercentage $2,3 \%$ bedraagt bij een vacaturegraad van 4,5\%. Gemiddeld genomen zou een werkloosheidspercentage van $2,3 \%$ volgens de figuur echter bij een vacaturegraad van ongeveer 3\% horen. Gegeven de vacaturegraad in Utrecht is het werkloosheidspercentage daar dus vrij hoog. De aansluiting is volgens deze figuur echter het slechtst in Groot-Amsterdam (punt 23). In Groot-Amsterdam is het werkloosheidspercentage namelijk een stuk hoger (circa 4,1\%) dan in Utrecht (circa 2,3\%), terwijl de vacaturegraad in Groot-Amsterdam (4,8\%) slechts marginaal hoger is dan in Utrecht $(4,5 \%)$.

De regionale aansluiting tussen vraag en aanbod in Oost-Zuid-Holland (punt 28), MiddenNoord-Brabant (punt 34), Zuidwest-Overijssel (punt 11) en Alkmaar en omgeving (punt 19) kan als gemiddeld getypeerd worden. Deze corop-gebieden bevinden zich op (of vlakbij) de rode geschatte lijn en scoren dus wat betreft de aansluiting gemiddeld.

\subsubsection{Ervaren aansluiting}

Figuur 2 geeft, evenals Figuur 1, een indicatie van de regionale aansluiting. Ditmaal wordt er gekeken naar het verband tussen enerzijds de ratio werkloosheidspercentage/vacaturegraad, i.e. de U/V-ratio, van de verschillende corop-regio's (CBS/StatLine) en anderzijds de aansluiting $^{7}$ in diezelfde regio's (ROA/SIS). De variabele 'aansluiting' geeft aan hoe werkzame MBO-gediplomeerden de aansluiting tussen de gevolgde opleiding en de arbeidsmarkt ervaren en wordt gemeten op een 4-puntsschaal (1=slecht, 2=matig,

\footnotetext{
${ }^{7}$ Naast de aansluiting is er ook gekeken naar het verband tussen de U/V-ratio en spijt. Aangezien het geschatte lineaire verband geen significante resultaten oplevert, wordt deze figuur niet in dit rapport weergegeven.
} 
3=voldoende en 4=goed). De variabele 'aansluiting' is een rangschikbaar kwalitatief kenmerk. Figuur 2 laat het verband zien tussen enerzijds de kwaliteit van de regionale aansluiting tussen de gevolgde opleiding en de arbeidsmarkt en anderzijds de arbeidsmarktsituatie in de betreffende regio. Het gaat hierbij dus om de door MBOgediplomeerden ervaren regionale aansluiting.

Figuur 2 De door MBO-gediplomeerden ervaren regionale aansluiting: de U/V-ratio en aansluiting in 2008

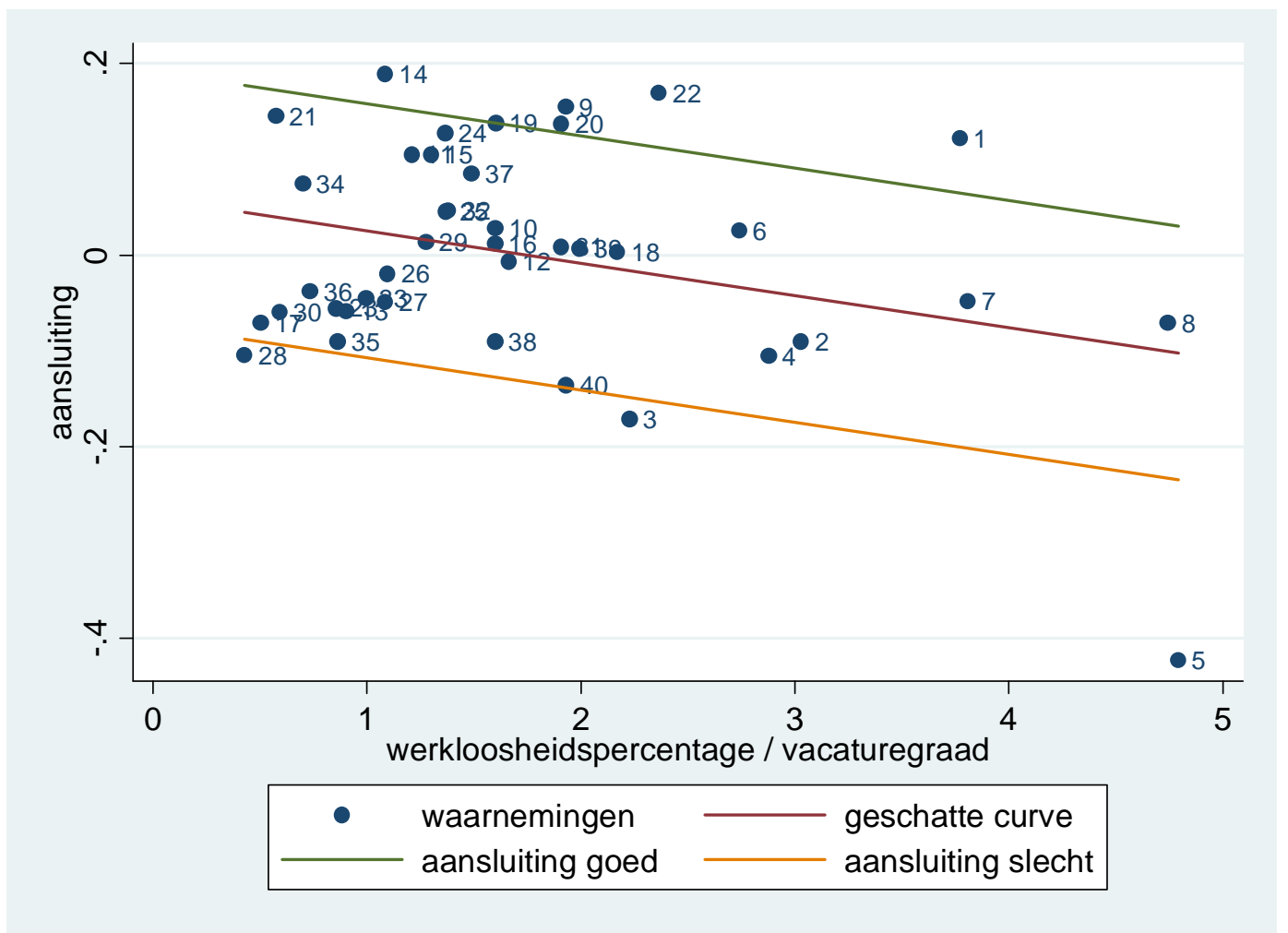

Bron: CBS (StatLine)/ROA (SIS)

Figuur 2 laat het lineaire verband zien tussen enerzijds de U/V-ratio en anderzijds de aansluiting $^{8}$ zoals werkzame MBO-gediplomeerden uit de verschillende corop-gebieden ${ }^{9}$ deze ervaren hebben. De rode lijn in de figuur geeft dit lineair geschatte verband weer en is significant negatief $(\beta=-0,034)$ bij een betrouwbaarheidsinterval van $95 \%$ ( $p$-waarde $=$ 0,049). Zoals eerder vermeld is de vraagzijde van de arbeidsmarkt 'driver'. Als bijvoorbeeld het aantal openstaande vacatures in een regio daalt dan resulteert dit in een toename van het

\footnotetext{
${ }^{8}$ Het lineaire verband is geschat door de variabele 'aansluiting' eerst te 'middelen', d.w.z. iedere waarde wordt gedeeld door de gemiddelde waarde. De waarde ' 0 ' voor aansluiting in Figuur 2 geeft de gemiddelde waarde voor aansluiting weer. De gemiddelde aansluiting is 3,09 wat dus iets boven de waarde 3 (i.e. voldoende) ligt.

${ }^{9}$ Punt 5 (Zuidwest-Friesland) is een zogenaamde 'outlier', die de analyse zou kunnen verstoren. Het verband tussen de U/V-ratio en aansluiting is daarom ook geschat zonder punt 5 mee te nemen. Dit leidt echter tot dezelfde resultaten.
} 
werkloosheidsniveau in die regio. De U/V-ratio zal dan toenemen, wat een negatief effect heeft op de door MBO-gediplomeerden ervaren aansluiting in die regio.

Ook in deze figuur wordt een bandbreedte ( 8 maal standaarddeviatie) weergegeven, zodat duidelijk zichtbaar is welke regio's beter of slechter dan gemiddeld scoren. De groene lijn geeft aan dat er in het gebied boven deze lijn sprake is van een goede ${ }^{10}$ aansluiting, terwijl de oranje lijn aangeeft dat er onder deze lijn sprake is van een slechte aansluiting.

Regio's die goed scoren qua ervaren aansluiting zijn de Achterhoek (punt 14), ZuidwestDrenthe (punt 9), IJmond (punt 20), Zaanstreek (punt 22) en Oost-Groningen (punt 1). MBOgediplomeerden die werken in bovengenoemde regio's geven aan dat er een goede aansluiting is tussen de gevolgde opleiding en de arbeidsmarkt. De aansluiting van Alkmaar en omgeving (punt 19) bevindt zich op de grens tussen redelijk en goed.

Oost-Zuid-Holland (punt 28), Overig Groningen (punt 3) en met name Zuidwest-Friesland (punt 5) scoren slecht wat betreft de aansluiting tussen opleiding en arbeidsmarkt. Werkzame MBO-gediplomeerden uit Flevoland (punt 40) ervaren deze aansluiting als slecht/matig.

Regio's die op (of dichtbij) de rode geschatte lijn liggen scoren gemiddeld qua aansluiting, zoals deze ervaren wordt door werkzame MBO-gediplomeerden gegeven een bepaalde U/Vratio. Dit geldt vooral voor Groot-Rijnmond (punt 29), Zuidwest-Gelderland (punt 16) en Twente (punt 12).

\subsubsection{Het verband tussen kwantitatieve en ervaren regionale aansluiting}

Vooralsnog zijn de twee geschatte verbanden (zie Figuur 1 en 2) die beide een indicatie van de regionale aansluiting weergeven afzonderlijk besproken. Het is echter ook mogelijk dat een bepaald corop-gebied goed (c.q. slecht) scoort op beide indicatoren, i.e. zowel qua kwantitatieve als ervaren aansluiting. Om te bekijken of er een relatie bestaat tussen kwantitatieve en ervaren aansluiting worden enkele corop-gebieden uitgelicht en nader besproken (zie voor een overzicht ook Tabel 1).

\footnotetext{
${ }^{10}$ De termen 'goede' en 'slechte' aansluiting hebben hier betrekking op het feit hoe goed of slecht regio's scoren ten opzichte van de gemiddelde aansluiting (met waarde 0). Het heeft niet betrekking op de scores van 1 (slecht) $\mathrm{t} / \mathrm{m} 4$ (goed) die respondenten gegeven hebben om de aansluiting te kwalificeren.
} 
Allereerst worden de corop-gebieden die een goede kwantitatieve aansluiting (zie Figuur 1) hebben besproken: Kop van Noord-Holland (punt 18) en Zuidwest-Friesland (punt 5). Zoals blijkt uit Figuur 2 kan de door MBO-gediplomeerden ervaren aansluiting van Kop van NoordHolland, in tegenstelling tot de kwantitatieve aansluiting in Figuur 1, niet als goed getypeerd worden. Werkzame MBO-gediplomeerden die in dit corop-gebied werken beoordelen de aansluiting tussen opleiding en baan echter wel nog altijd als iets beter dan gemiddeld. Voor Zuidwest-Friesland is het contrast tussen de kwantitatieve en ervaren aansluiting nog groter. Uit Figuur 2 kan geconcludeerd worden dat MBO-gediplomeerden uit Zuidwest-Friesland de aansluiting het slechtst beoordelen van MBO-gediplomeerden uit alle corop-gebieden. Een verklaring hiervoor zou kunnen zijn dat gediplomeerde MBO'ers een baan aanvaarden die eigenlijk niet goed past bij hun opleidingsachtergrond puur en alleen met de intentie om aan de slag te raken (i.e. een goede kwantitatieve aansluiting in Figuur 1), terwijl deze personen feitelijk helemaal niet zo tevreden zijn over de aansluiting (i.e. een slechte aansluiting in Figuur 2).

Tevens vergelijken we beide aansluitingsindicatoren voor twee corop-gebieden die slecht scoorden wat betreft kwantitatieve aansluiting (zie Figuur 1): Utrecht (punt 17) en Agglomeratie Haarlem (punt 21). Ervaren de werkzame MBO-gediplomeerden uit deze regio's de aansluiting tussen de door hen gevolgde opleiding en de arbeidsmarkt ook als slecht? Uit Figuur 2 blijkt dat Utrecht slechter scoort dan gemiddeld (i.e. Utrecht scoort matig) met betrekking tot de aansluitingsindicator die aangeeft hoe MBO-gediplomeerden de aansluiting ervaren. Nog opvallender is dat de ervaren aansluiting voor MBO-gediplomeerden werkzaam in de Agglomeratie Haarlem in Figuur 2 als bovengemiddeld (i.e. redelijk/goed) getypeerd kan worden, terwijl de kwantitatieve aansluiting in Figuur 1 als slecht getypeerd kon worden.

Er lijkt geen duidelijk verband te bestaan tussen de kwantitatieve en de ervaren aansluiting in een regio. Zowel regio's met een lage U/V-ratio (bijvoorbeeld punt 14) als regio's met een hoge U/V-ratio (bijvoorbeeld punt 1) laten een goede door MBO-gediplomeerden ervaren aansluiting zien. Men zou kunnen beredeneren dat bij een hoge vacaturegraad in een regio de aanbodkant op de arbeidsmarkt een sterke positie heeft. Immers, bij veel openstaande vacatures hebben werkzoekenden veel keuze, waardoor ze die baan kunnen kiezen die het beste aansluit bij hun opleiding. Men zou dus kunnen concluderen dat een hoge vacaturegraad leidt tot een lage U/V-ratio wat op haar beurt weer leidt tot een goede ervaren aansluiting 
tussen gevolgde opleiding en arbeidsmarkt (zie punt 14). Anderzijds zou men echter ook kunnen beredeneren dat bij een lage vacaturegraad in een regio de vraagkant op de arbeidsmarkt een sterke positie heeft. Immers, bij weinig openstaande vacatures hebben werkgevers veel keuze uit het grote aanbod van arbeidskrachten. Werkgevers kunnen dan die persoon in dienst nemen waarvan de opleiding het beste bij de functie aansluit. Men zou dus kunnen concluderen dat een lage vacaturegraad leidt tot een hoge U/V-ratio wat op haar beurt weer leidt tot een goede ervaren aansluiting tussen gevolgde opleiding en arbeidsmarkt (zie punt 1). 
Tabel 1 Kwantitatieve en door MBO-gediplomeerden ervaren regionale aansluiting in 2008

\begin{tabular}{|c|c|c|c|}
\hline NR & COROP-gebied & Kwantitatieve aansluiting & $\begin{array}{l}\text { Ervaren } \\
\text { aansluiting }\end{array}$ \\
\hline 1 & Oost-Groningen & Voldoende & Goed \\
\hline 2 & Delfzijl en omgeving & (niet meegenomen) & Matig \\
\hline 3 & Overig Groningen & Matig & Slecht \\
\hline 4 & Noord-Friesland & Voldoende & Matig \\
\hline 5 & Zuidwest-Friesland & Goed & Slecht \\
\hline 6 & Zuidoost-Friesland & Voldoende & Voldoende \\
\hline 7 & Noord-Drenthe & Voldoende & Voldoende \\
\hline 8 & Zuidoost-Drenthe & Voldoende & Voldoende \\
\hline 9 & Zuidwest-Drenthe & Voldoende & Goed \\
\hline 10 & Noord-Overijssel & Matig & Voldoende \\
\hline 11 & Zuidwest-Overijssel & Voldoende & Voldoende \\
\hline 12 & Twente & Voldoende & Matig \\
\hline 13 & Veluwe & Matig & Matig \\
\hline 14 & Achterhoek & Voldoende & Goed \\
\hline 15 & Arnhem / Nijmegen & Matig & Voldoende \\
\hline 16 & Zuidwest-Gelderland & Matig & Voldoende \\
\hline 17 & Utrecht & Slecht & Matig \\
\hline 18 & Kop van Noord-Holland & Goed & Voldoende \\
\hline 19 & Alkmaar en omgeving & Gemiddeld & Voldoende/Goed \\
\hline 20 & IJmond & Matig & Goed \\
\hline 21 & Agglomeratie Haarlem & Slecht & Voldoende \\
\hline 22 & Zaanstreek & Matig & Goed \\
\hline 23 & Groot-Amsterdam & Slecht & Matig \\
\hline 24 & Het Gooi en Vechtstreek & Matig & Voldoende \\
\hline 25 & Agglomeratie Leiden en Bollenstreek & Matig & Voldoende \\
\hline 26 & Agglomeratie 's-Gravenhage & Matig & Matig \\
\hline 27 & Delft en Westland & Voldoende & Matig \\
\hline 28 & Oost-Zuid-Holland & Gemiddeld & Slecht \\
\hline 29 & Groot-Rijnmond & Slecht/matig & Gemiddeld \\
\hline 30 & Zuidoost-Zuid-Holland & Matig & Matig \\
\hline 31 & Zeeuwsch-Vlaanderen & Matig & Voldoende \\
\hline 32 & Overig Zeeland & Voldoende & Voldoende \\
\hline 33 & West-Noord-Brabant & Matig & Matig \\
\hline 34 & Midden-Noord-Brabant & Matig & Voldoende \\
\hline 35 & Noordoost-Noord-Brabant & Voldoende & Matig \\
\hline 36 & Zuidoost-Noord-Brabant & Matig & Matig \\
\hline 37 & Noord-Limburg & Voldoende & Matig \\
\hline 38 & Midden-Limburg & Matig & Matig \\
\hline 39 & Zuid-Limburg & Voldoende & Voldoende \\
\hline 40 & Flevoland & Voldoende & Slecht/matig \\
\hline
\end{tabular}

Bron: CBS Statline/ROA (SIS) 


\section{Verklarend model voor aansluiting}

Tabel 2 en 3 geven de resultaten weer van een logistische regressieanalyse die voor werkzame MBO-gediplomeerden de kans voorspelt op een voldoende aansluiting tussen de gevolgde opleiding en de huidige baan. Tabel 2 geeft de invloed weer van verschillende onafhankelijke variabelen op de kans dat werkzame MBO-gediplomeerden de aansluiting tussen de gevolgde opleiding en de huidige baan als 'voldoende' (i.e. voldoende of goed) ervaren (ten opzichte van 'onvoldoende', i.e. matig of slecht). De corop-gebieden worden met dummyvariabelen aangegeven. Tabel 3 laat een vergelijkbare analyse zien. Echter de dummyvariabelen zijn hier vervangen door verschillende andere regiovariabelen. Om de interpreteerbaarheid van de resultaten te vergroten worden de resultaten van beide regressieanalyses gepresenteerd in de vorm van marginale effecten. De resultaten van deze analyses hebben betrekking op 2008.

Allereerst valt op dat, van de verschillende persoonskenmerken die in de analyses meegenomen worden, de variabelen geslacht, leeftijd en etniciteit geen significante invloed hebben op hoe gediplomeerde MBO'ers de ansluiting beoordelen. Gediplomeerde MBO'ers van de beroepsbegeleidende leerweg (BBL) beoordelen de transitie tussen onderwijs en arbeidsmarkt significant vaker als 'voldoende' dan equivalenten van de beroepsopleidende leerweg (BOL). MBO-gediplomeerden met een BBL-achtergrond hebben tijdens hun opleiding vaak stages gevolgd bij bedrijven. Het voordeel hiervan is dat de eerste baan vaak voortvloeit uit één van deze stages. Dit verklaart waarom BBL'ers de aansluiting significant beter vinden dan BOL'ers. Daarnaast speelt het niveau van de MBO-opleiding een significante rol. De kans dat de aansluiting tussen onderwijs en arbeidsmarkt een 'voldoende' scoort is significant hoger bij gediplomeerden met opleidingsniveau 3 ten opzichte van opleidingsniveau 4. Werkzame MBO-gediplomeerden met een diploma richting gedrag en maatschappij en met name richting gezondheidszorg ervaren de aansluiting tussen de gevolgde opleiding en de huidige baan als significant beter dan degenen die een opleiding richting economie gevolgd hebben. Als laatste is de kans dat de aansluiting een 'voldoende' geniet groter bij werkzame MBO-gediplomeerden uit corop-gebied 21 (Agglomeratie Haarlem), ten opzichte van corop-gebied 17 (Utrecht). Dit is ook duidelijk te zien in Figuur 2 waar punt 21 ruim boven de gemiddelde aansluiting ligt (dicht tegen de bandbreedte van een goede aansluiting aan) terwijl punt 17 ruim onder de gemiddelde aansluiting ligt (dicht tegen de bandbreedte van een slechte aansluiting aan). 
Tabel 2 Regressieresultaten voor de kans op een voldoende/goede aansluiting van de gevolgde opleiding voor MBO-gediplomeerden in 2008, marginale effecten op basis van logistische regressie

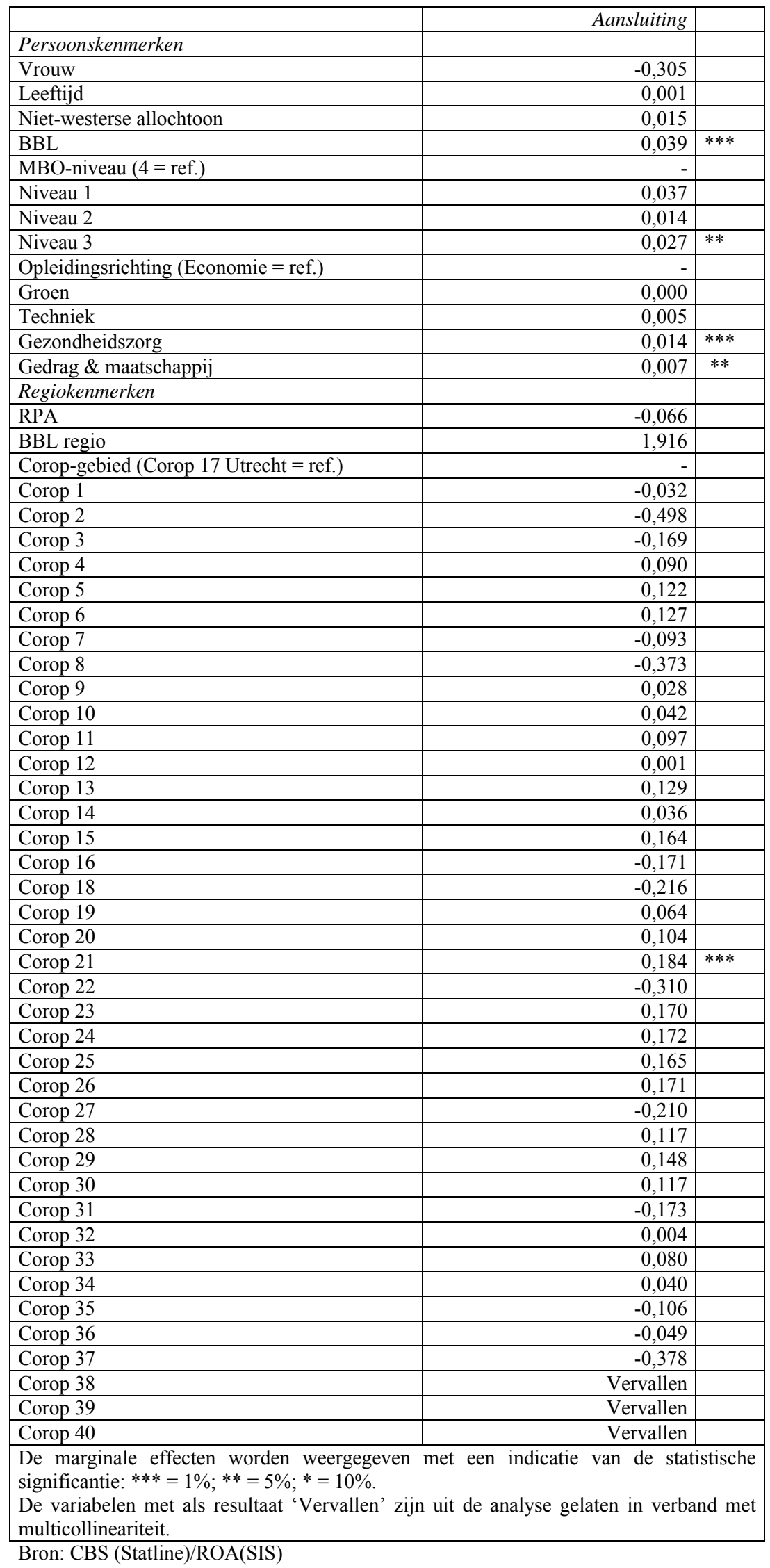


Tabel 3 Regressieresultaten voor de kans op een voldoende/goede aansluiting van de gevolgde opleiding voor MBO-gediplomeerden in 2008, marginale effecten op basis van logistische regressie

\begin{tabular}{|c|c|c|}
\hline & Aansluiting & \\
\hline \multicolumn{3}{|l|}{ Persoonskenmerken } \\
\hline Vrouw & 0,008 & \\
\hline Leeftijd & 0,001 & \\
\hline Niet-westerse allochtoon & 0,013 & \\
\hline $\mathrm{BBL}$ & 0,039 & $* * *$ \\
\hline MBO-niveau (4 = ref.) & - & \\
\hline Niveau 1 & 0,039 & \\
\hline Niveau 2 & 0,018 & \\
\hline Niveau 3 & 0,026 & $* *$ \\
\hline Opleidingsrichting (Economie $=$ ref.) & - & \\
\hline Groen & 0,003 & \\
\hline Techniek & 0,005 & \\
\hline Gezondheidszorg & 0,013 & $* * *$ \\
\hline Gedrag \& maatschappij & 0,007 & $* *$ \\
\hline \multicolumn{3}{|l|}{ Regiokenmerken } \\
\hline RPA & $-0,010$ & \\
\hline BBL regio & $-0,014$ & \\
\hline Werkloosheidspercentage & $-0,008$ & \\
\hline Vacaturegraad & $-0,004$ & \\
\hline Bruto participatiegraad & Vervallen & \\
\hline Percentage jongeren & $-0,001$ & \\
\hline Percentage ouderen & $-0,002$ & \\
\hline Vergrijzing & 0,007 & \\
\hline Landbouw & Vervallen & \\
\hline Nijverheid / Energie & 0,000 & \\
\hline Commerciële dienstverlening & Vervallen & \\
\hline Niet-commerciële dienstverlening & Vervallen & \\
\hline Niet-westerse allochtoon regio & 0,001 & \\
\hline Woningwaarde & Vervallen & \\
\hline \multicolumn{3}{|c|}{$\begin{array}{l}\text { De marginale effecten worden weergegeven met een indicatie van de } \\
\text { statistische significantie: } * * *=1 \% ; * *=5 \% ; *=10 \% \text {. } \\
\text { De variabelen met als resultaat 'Vervallen' zijn uit de analyse gelaten in } \\
\text { verband met multicollineariteit. }\end{array}$} \\
\hline
\end{tabular}

Bron: CBS (Statline)/ROA(SIS)

Tabel 2 en 3 zijn uitgevoerd met een 'strikte' definitie van RPA (zie voor meer informatie Tabel 4 in de bijlage). De analyses zijn ook uitgevoerd met een 'ruime' definitie van RPA, wat dezelfde resultaten genereert. Naast aansluiting zijn de analyses ook uitgevoerd met spijt als afhankelijke variabele. Dit resulteert in een significant negatief effect van nijverheid/energie (in het geval van een ruime RPA in combinatie met regiovariabelen), een significant negatief effect van vergrijzing (in het geval van een strikte RPA in combinatie met regiovariabelen) en een significant negatief effect van RPA (in het geval van een strikte RPA in combinatie met regiodummy's) op de kans dat MBO-gediplomeerden spijt hebben van de gekozen opleiding. Dit betekent dat de kans op het hebben van spijt kleiner is als er in een bepaalde regio meer economische 
activiteit plaatsvindt in de sector nijverheid/energie, er meer vergrijzing is en er een RPA aanwezig is.

Verder blijken er nog enkele onafhankelijke variabelen significant van invloed te zijn op het hebben van spijt van de gekozen opleiding. Leeftijd heeft bijvoorbeeld een significant negatief effect op spijt, wat betekent dat oudere MBO-gediplomeerden minder spijt hebben van de gevolgde opleiding. Niet-westerse allochtonen hebben daarentegen vaker spijt van de gevolgde opleiding. Wat betreft het niveau van de MBO-opleiding kan geconcludeerd worden dat gediplomeerden van de lagere niveaus ( 1 en 2 ) significant vaker aangeven spijt te hebben van de gevolgde opleiding dan gediplomeerden van niveau 4. Verder blijkt dat MBOgediplomeerden richting gezondheidszorg, gedrag en maatschappij en met name techniek significant minder vaak spijt hebben van de gevolgde opleiding dan gediplomeerden uit een economische richting.

\section{Samenvatting}

Dit werkdocument is een eerste verkenning op het gebied van de regionale aansluitingsproblematiek tussen onderwijs en arbeidsmarkt voor het middelbaar beroepsonderwijs. Ondanks deze beknopte inventarisatie kunnen we toch een algemeen beeld schetsen van de mate van aansluiting voor de verschillende corop-gebieden.

Uit Figuur 1 blijkt dat er inderdaad een significant negatief verband bestaat tussen de vacaturegraad en het werkloosheidspercentage voor MBO-gediplomeerden van de 40 Nederlandse corop-gebieden in 2008. Hierbij is de kwantitatieve aansluiting van Kop van Noord-Holland (punt 18) en Zuidwest-Friesland (punt 5) beter ten opzichte van het gemiddelde (i.e. de geschatte gemiddelde UV-curve), terwijl Utrecht (punt 17), Agglomeratie Haarlem (punt 21) en Groot-Amsterdam (punt 23) juist een slechtere kwantitatieve aansluiting laten zien.

Figuur 2 laat een significant negatief verband zien tussen de U/V-ratio en de aansluiting. Uit deze figuur blijkt dat de Achterhoek (punt 14), Zuidwest-Drenthe (punt 9), IJmond (punt 20), Zaanstreek (punt 22) en Oost-Groningen (punt 1) goed scoren qua ervaren aansluiting. Terwijl Oost-Zuid-Holland (punt 28), Overig Groningen (punt 3) en met name Zuidwest-Friesland 
(punt 5) juist slecht scoren wat betreft de ervaren aansluiting tussen opleiding en arbeidsmarkt.

Er lijkt geen duidelijk verband te bestaan tussen de kwantitatieve en de ervaren aansluiting in een regio. Zowel regio's met een lage U/V-ratio (bijvoorbeeld punt 14) als regio's met een hoge U/V-ratio (bijvoorbeeld punt 1) laten een goede ervaren aansluiting zien (zie Tabel 1).

Uit de logistische regressies in Tabel 2 en 3 blijkt dat de kans dat BBL'ers de aansluiting tussen de gevolgde opleiding en de arbeidsmarkt als 'voldoende' kwalificeren significant groter is. Dit betekent dat BBL'ers in het algemeen de aansluiting significant beter vinden dan BOL'ers. Bovendien scoren opleidingsniveau 3, en de opleidingsrichtingen gezondheidszorg en gedrag en maatschappij significant beter dan de referentiegroepen.

Er dient enige voorzichtigheid in acht genomen te worden bij bovenstaande conclusies aangezien de resultaten van de analyses niet allemaal even robuust zijn. De geschatte curves voor spijt waren bijvoorbeeld niet significant, terwijl dit voor aansluiting wel het geval was. Tevens zijn de resultaten van de logistische regressieanalyses niet erg robuust, want het blijkt dat het nogal een verschil maakt of we aansluiting of spijt als afhankelijke variabele nemen, de strikte of ruime RPA variabele nemen, en/of de regiovariabelen of de regiodummy's meenemen in de analyses.

Daarbij is een beperking van deze studie dat er gegevens van slechts één jaar worden meegenomen, te weten 2008. Om bepaalde tijdseffecten in acht te nemen zouden er eigenlijk meerdere meetpunten in de tijd moeten worden meegenomen. Er zou bijvoorbeeld een nulmeting (een meting vóórdat RPA's worden opgericht) kunnen worden meegenomen om te bekijken wat de mate van aansluiting is vóór het bestaan van RPA's, om vervolgens na te gaan hoe de mate van aansluiting is veranderd ná de oprichting van RPA's. ${ }^{11}$

Tevens kunnen door het gebruik van meerdere meetpunten in de tijd veranderingen op de arbeidsmarkt worden meegenomen. Het gaat hierbij niet zozeer om de hoogte van de werkloosheid, maar eerder om het verschil in werkloosheid op het moment dat de opleiding

${ }^{11}$ Dit, omdat de kans groot is dat RPA's waarschijnlijk met name worden opgericht in regio's waar de aansluiting tussen opleiding en arbeidsmarkt onvoldoende is, i.e. waar de behoefte voor RPA's het grootst is. 
gevolgd wordt en het moment waarop MBO-gediplomeerden de arbeidsmarkt betreden. Onderzoek heeft laten zien dat scholieren bij hun studiekeuze vaak uitgaan van de huidige arbeidsmarktverhoudingen en dus impliciet veronderstellen dat deze een goede weerspiegeling vormen van de kansen op werk en beloning in een beroep op het moment dat zij de arbeidsmarkt betreden. ${ }^{12}$

${ }^{12}$ Dit wordt de 'rational expectations' theorie genoemd. 


\section{Referenties}

Blanchard, O. J. en Diamond, P. (1989), The Beveridge curve, Brookings Papers on Economic Activity, 1, pp. 1-60.

Gorter, C., \& Van Ours, J. (1994), Matching Unemployment and Vacancies in Regional Labor Markets: An Empirical Analysis for the Netherlands, Papers in Regional Science, 73 (2), pp. 153-167.

Hilbert, C. (2008), Unemployment, Wages, and the Impact of Active Labour Market Policies in a Regional Perspective, dissertatie, Erasmus universiteit, Rotterdam.

Van Ours. J. C. (1991), The efficiency of the Dutch labour market in matching unemployment and vacancies, De Economist, 139 (3), pp. 358-378.

Valletta, R.G. (2005), Why has the U.S. Beveridge curve shifted back? new evidence using regional data, Working Paper Series 2005-25, Federal Reserve Bank of San Francisco.

Wall, H. J. \& Zoega, G. (2002), The British Beveridge curve: A tale of ten regions, Oxford Bulletin of Economics and Statistics, 64 (3), pp. 257-276. 


\section{Bijlage}

\section{Huidige stand van zaken RPA's}

Als startpunt van voorliggend onderzoek wordt eerst kort ingegaan op de huidige stand van zaken betreffende het bestaan van RPA's. Sinds de invoering van de meeste regionale arbeidsmarktplatforms in 2000/2001 zijn er inmiddels diverse opgeheven. Het blijkt echter niet eenvoudig om voor bepaalde RPA's te achterhalen of deze nog actief zijn of dat deze in het verleden reeds opgeheven zijn. Sommige lijken dan ook een sluimerend bestaan te leiden. Enkele RPA's hebben wel nog een website, maar in enkele gevallen is deze al geruime tijd niet meer bijgewerkt. Indien er geen recente projecten of nieuwsbrieven meer op een website geplaatst zijn, rijst natuurlijk de vraag in hoeverre nog gesproken kan worden van een actief RPA. Ook komt het voor dat contactgegevens niet meer up-to-date zijn, of dat contactpersonen moeilijk bereikbaar zijn.

Er zijn echter ook diverse RPA's die duidelijk wel op een actieve manier de aansluiting tussen onderwijs en arbeidsmarkt trachten te verbeteren. Na telefonisch contact met medewerkers van een behoorlijk aantal van deze RPA's die momenteel nog actief zijn, blijkt dat deze met name op de hoogte zijn van wat zich afspeelt binnen hun eigen RPA-gebied. In het algemeen blijken zij daarentegen niet altijd op de hoogte van het bestaan van andere RPA's in Nederland. Indien gevraagd kunnen sommigen wel aangeven of RPA's in aangrenzende regio's nog actief zijn, maar er zijn ook voorbeelden dat medewerkers van RPA's niet konden vertellen of er nog andere RPA's in de betreffende provincie actief zijn en zo ja welke. Geen van de gesproken medewerkers kon ons een compleet overzicht met de huidige actieve RPA's verschaffen. Wel hebben sommige RPA's links naar de websites van andere RPA's op hun andere website staan, maar meestal gaat het hier slechts om enkele links. De link naar het Landelijk Overleg Regionale Platforms Arbeidsmarktbeleid (LORPA) werkt bovendien helemaal niet meer. 
Tabel 4 RPA-indeling in een 'ruime' RPA en een 'strikte' RPA variabele ( 1 = aanwezigheid RPA, 0 = afwezigheid RPA)

\begin{tabular}{|c|c|c|c|}
\hline NR & Corop-gebeid & 'ruime' RPA & 'strikte' RPA \\
\hline 1 & Oost-Groningen & 1 & 1 \\
\hline 2 & Delfzijl en omgeving & 1 & 1 \\
\hline 3 & Overig Groningen & 1 & 1 \\
\hline 4 & Noord-Friesland & 0 & 0 \\
\hline 5 & Zuidwest-Friesland & 0 & 0 \\
\hline 6 & Zuidoost-Friesland & 0 & 0 \\
\hline 7 & Noord-Drenthe & 1 & 0 \\
\hline 8 & Zuidoost-Drenthe & 0 & 0 \\
\hline 9 & Zuidwest-Drenthe & 0 & 0 \\
\hline 10 & Noord-Overijssel & 0 & 0 \\
\hline 11 & Zuidwest-Overijssel & 0 & 0 \\
\hline 12 & Twente & 1 & 1 \\
\hline 13 & Veluwe & 1 & 1 \\
\hline 14 & Achterhoek & 1 & 1 \\
\hline 15 & Arnhem / Nijmegen & 1 & 0 \\
\hline 16 & Zuidwest-Gelderland & 1 & 1 \\
\hline 17 & Utrecht & 1 & 0 \\
\hline 18 & Kop van Noord-Holland & 1 & 1 \\
\hline 19 & Alkmaar en omgeving & 1 & 1 \\
\hline 20 & IJmond & 1 & 1 \\
\hline 21 & Agglomeratie Haarlem & 1 & 1 \\
\hline 22 & Zaanstreek & 0 & 0 \\
\hline 23 & Groot-Amsterdam & 1 & 1 \\
\hline 24 & Het Gooi en Vechtstreek & 0 & 0 \\
\hline 25 & Agglomeratie Leiden en Bollenstreek & 1 & 1 \\
\hline 26 & Agglomeratie 's-Gravenhage & 1 & 1 \\
\hline 27 & Delft en Westland & 1 & 1 \\
\hline 28 & Oost-Zuid-Holland & 1 & 1 \\
\hline 29 & Groot-Rijnmond & 1 & 1 \\
\hline 30 & Zuidoost-Zuid-Holland & 1 & 1 \\
\hline 31 & Zeeuwsch-Vlaanderen & 0 & 0 \\
\hline 32 & Overig Zeeland & 0 & 0 \\
\hline 33 & West-Noord-Brabant & 1 & 1 \\
\hline 34 & Midden-Noord-Brabant & 0 & 0 \\
\hline 35 & Noordoost-Noord-Brabant & 0 & 0 \\
\hline 36 & Zuidoost-Noord-Brabant & 0 & 0 \\
\hline 37 & Noord-Limburg & 1 & 1 \\
\hline 38 & Midden-Limburg & 1 & 1 \\
\hline 39 & Zuid-Limburg & 1 & 1 \\
\hline 40 & Flevoland & 1 & 1 \\
\hline
\end{tabular}

